\title{
APPEALING THE JUDGMENTS ISSUED IN CRIMINAL TRIAL WITH THE PARTICIPATION OF LAY JUDGES IN POLAND AND JURY IN ENGLAND
}

\begin{abstract}
The objective of the paper is to present the differences in the grounds of appeal and the appeal proceedings against judgments issued by a court composed of representatives of the public in a criminal trial at first instance. At present, citizens are allowed to adjudicate most often in one of three forms: persons adjudicating independently without the participation of a professional factor, who are not professionals in the field of law and criminal procedure (e.g. judges of the peace in the common law system); a jury composed of citizens and adjudicating mostly on guilt of the accused; or lay judges adjudicating all aspects of the case in one panel together with professional judges. However, the participation of laymen in adjudication is not a prevailing rule. Many countries legal systems do not allow the citizens to co-decide in criminal cases. The paper also indicates the arguments for the democratization of the judiciary through a wider admission of citizens to participate in criminal justice. This issue has been examined on the background of three aspects of democracy: representative, deliberative and participatory.
\end{abstract}

Keywords: democracy, criminal trial, appeal proceedings, lay judge, jury.

\section{Introduction}

One of the determinants of a democratic state ruled by law is the cooperation of state authorities with citizens to properly implement the tasks imposed on them. The cooperation in the field of justice is particularly important. Despite the far-reaching professionalism of the representatives of the judiciary, the legal systems of contemporary democratic states commonly allow the representatives of society to participate in adjudication.

The representative of the community in the judiciary is defined as persons who do not have professional qualifications to adjudicate, and who 
perform their non-professional functions as a volunteer activity without receiving remuneration (possibly with reimbursement or monetary compensation) (Włodyka, 1975). In the doctrine sometimes the principle of the participation of a representative of the community in criminal proceedings is formulated, which requires the authorities of the criminal trial to allow citizens to participate in criminal proceedings whenever a specific provision makes such a possibility, especially when the initiative to participate in the procedure comes from the citizens themselves (Janusz-Pohl, 2014). This principle is a manifestation of the democratization of the judiciary and the process of applying the law, and is closely related to the constitutional principles of a democratic state ruled by law (Article 2 of the Polish Constitution of 2 April 1997') and civil society (Articles 11, 12 and 16 of the Polish Constitution) which assume public participation in the performance of state power (Zagrodnik, 2017). The principle of participation by the citizenry in the administration of justice has been formulated in Article 182 of the Polish Constitution. On the other hand, the Act of 6 June 1997 - Code of Criminal Procedure ${ }^{2}$ enigmatically states in Article 3 the principle of the participation of a representative of the community in criminal proceedings ("Within the scope set forth by the law, criminal proceedings shall be conducted with the participation of a representative of the community").

The main thesis of this paper is as follows: significant differences in appealing the judgments issued by the court with the participation of lay judges and the jury verdicts result from separate tasks performed by both bodies.

\section{The role of the representative of the community in criminal trial}

The adjudication of cases should not be the task of only a small legal elite. Citizens should be allowed to take part in the criminal trial as representatives of the population at large who protect other citizens against the omnipotence of the state. In addition, the discourse undertaken with the participation of the representatives of the community as part of creating trial decisions is aimed at building citizens' trust in the judiciary and the state itself, as well as strengthening the legitimacy of power. Citizens are able to form their own opinion on the legal system and judiciary. The representatives of the community also strengthen the guarantees of the principle of direct and oral procedure in court (Malsch, 2016). 
Participation by citizens in the criminal trial is associated with the following aspects of democracy: representation, deliberation and participation. Representative democracy enables people of different professions and from different social groups to represent the society in the justice system. Deliberative democracy can be defined as an informed debate among equal and rational citizens. As part of criminal proceedings it consists of: debate within adjudicating panels on cases, sharing of experience by lay adjudicators at the local level and publicly, reasons given for court decisions, media reporting, articles and books on the criminal trial, and debate within society on the criminal justice system. Participative democracy makes it possible for citizens to decide on matters that concern them directly or that are relevant to the general public, as well as to exercise control over state powers. In the framework of the criminal justice system, this type of democracy involves: taking part in the preparation of a trial by reading case files, asking questions during the hearing of the accused, witnesses or experts, taking part in the discussions during deliberations on the ruling, and playing an important role (which is theoretically equal with professional judges) in the decision-making on the accused's guilt and punishment (Malsch, 2016).

Participation of citizens in adjudicating may take the form of citizens' courts composed only of non-professionals (e.g. justice of the peace or lay magistrate in some Anglo-Saxon countries and juge de proximité in France), mixed panels composed of professional judges and lay judges (e.g. in Germany, Austria, Poland, Sweden, Finland, Italy, Greece and Portugal) and jury deciding the facts and guilt (mainly in Anglo-Saxon countries as well as France, Spain or since the 1990s in Russia) (Bartnik, 2009; Kovalev, 2010; Wieczorek, 2012; Zagrodnik, 2017).

In addition in a small number of countries there is an advisory lay assessor whose task is to issue a recommendation on the accused's guilt, but the judge adjudicating the case is not bound by such a decision. The nonbinding nature of the recommendation means that an advisory lay assessor is not considered to take part in adjudication (Sikich, 2013).

\section{Appealing the judgments issued with the participation of lay judges}

The appeal proceedings against judgments given by the panel with the participation of lay judges are governed by analogous rules as in the case of judgments issued only by professional judges. However, the dissenting 


\section{Dariusz Kużelewski}

opinion (votum separatum) may be of significant importance. It can be used only when adjudicating in a multi-person panel, both professional and with the participation of lay judges. Each member of the panel pursuant to Article $114 \S 1$ of the Code of Criminal Procedure is authorised, when signing the decision, to express his dissenting opinion, stating which part and direction of the judgement he questions. The above right can only be used when signing the decision. Any subsequent statements made after signing and announcing the judgment do not constitute a dissenting opinion $^{3}$. A dissenting opinion may also relate to the reasons for the decision; and shall be indicated when the reasons for the decision are signed (Article $114 \S 2$ ).

The expression of a dissenting opinion gives the appellants a kind of weapon. It may above all lead the person concerned to lodge an appeal and, secondly, give appropriate arguments to be used in the appeal. The view of the Supreme Court expressed under the Code of Criminal Procedure of 1969, that the dissenting opinion and its justification is available to the parties and may be used by them in the preparation of an appeal still remains valid $^{4}$. The mere fact of expressing a dissenting opinion indicates a lack of unanimity in the adjudication panel and may raise doubts as to the equity of the first-instance judgment. It should be presumed that the wider is the scope of the dissenting opinion, and hence the contested decisions or findings by a professional or lay judge, the more convinced to lodge an appeal should be the applicant and the more vigilant should be the appeal court when examining such an appeal. The above thesis is confirmed by research on the participation of lay judges in criminal proceedings carried out in Poland in the 1960s (Zawadzki, Kubicki, 1970).

As in the case of an appeal procedure, the provisions of the Polish Code of Criminal Procedure do not differentiate between the grounds of appeal depending on the type of adjudicating panel. Among the absolute grounds of appeal, the conditions indicated in Article $439 \S 1$ items 1, 2 and 6 of the Code of Criminal Procedure are particularly characteristic as far as multiperson panels are concerned. If such grounds occur, the appeal court at the session shall reverse the decision subject to review, irrespective of the limits established for the appellate measure and of the effect of the violation on the contents of the decision.

The grounds for reversal of the judgment referred to in Article 439 $\S 1$ item 1 applies to three categories of persons: not authorized to adjudicate, unable to adjudicate and subject to disqualification by virtue of law on the basis of the conditions specified in Article 40 of the Code of Criminal Procedure. In all these cases it is about participation in issuing the 
judgment, i.e. not only in the rendering of the judgment (the deliberation, voting, preparation, signing and announcement of the judgment), but also in participation in all procedural actions leading to issue the judgement, e.g. evidence proceedings during the main trial.

An unauthorized person is a person who does not have the authority to adjudicate in any court or case at all (Hofmański, Sadzik, Zgryzek, 2011). An unauthorized to adjudicate person should certainly be a lay judge selected by a resolution of the commune council or city council regarding the selection of lay judges, which was subject to a legal defect and cancelled (Wieczorek, 2012), as well as a lay judge who has not made an oath and whose term of office has expired, unless the case began before the end of the term of office) (Boratyńska, Czarnecki, 2018).

A person who in principle is authorized to adjudicate can be considered as unable to do so in specific circumstances while adjudicating which may cause a distortion of the content of the judgement. For example, one should not participate in adjudicating while being under the influence of alcohol or intoxicants, totally or partially insane, not able to recognize the meaning of procedural decisions to be taken due to mental or physical illness or coercion (Hofmański, Sadzik, Zgryzek, 2011).

The third group of entities covered by the provision of Article $439 \S 1$ item 1 of the Code of Criminal Procedure are judges and lay judges subject to ex lege disqualification based on the catalogue of situations specified in Article $40 \S 1$.

Another of the discussed grounds for reversing decision referred to in Article $439 \S 1$ item 2 of the Code of Criminal Procedure applies to situations where the panel was improperly selected or any of its members was not present at the entire trial.

An improperly selected panel is a panel unknown to the law, as well as not provided for by the law for a given type of case. Polish law does not provide for panels composed of an even number of judges or panels with a predominance of professional judges over lay judges (except for Supreme Court panels hearing an extraordinary complaint and adjudicating in disciplinary proceedings). An example of the second situation may be the recognition of a case by a district court composed of two judges and three lay judges, which composition, in accordance with the provisions of the Code of Criminal Procedure, may only appear before a regional court in cases of crimes punishable by life imprisonment. Therefore, such a composition exists in the system of Polish law, but not in a given court or case. An improperly selected panel is also a panel which consists of a different number of judges and lay judges that have taken part in the adjudication than pro- 
vided for in the law (also a greater number of additional judges and lay judges than provided for in the law, on condition that they have been appointed in the case), as well as when judges have taken part in the panel instead of lay judges or vice versa or when a member of the panel did not have the right to adjudicate in a given court (e.g. a lay judge elected to another court).

On the other hand, there has been divergence in doctrine and jurisprudence as to the situation in which the provisions provide for the possibility of hearing the case in various configurations of the adjudicating panel, i.e. in the basic or modified composition based on the judge's decision. An example of such a situation is Article $28 \S 3$ of the Code of Criminal Procedure, pursuant to which the court of first instance, due to the particular complexity of the case or its importance, may decide to hear it in a panel of three judges or one judge and two lay judges. At present, there is a tendency to treat the failure to issue an appropriate procedural decision as an organizational error of the trial authority, and not as a fault constituting an absolute ground of appeal (Hofmański, Sadzik, Zgryzek, 2011).

The absence of any member of the adjudicating panel during the entire hearing occurs when he or she does not participate in it at least for a short period of time from the moment the case is called to the closing of the hearing after the announcement of the judgment, giving orally the most important reasons and informing the parties about the time and procedure for lodging an appeal. This also applies to an additional judge or lay judge who, if he or she has not participated in any part of the trial, will not be able to replace a basic judge or lay judge and adjudicate.

The last of the discussed appeal reasons, i.e. violation of the principle of majority of votes listed in Article $439 \S 1$ item 6 of the Code of Criminal Procedure, due to the secrecy of the deliberation and voting, has little chance to be disclosed. As indicated in the doctrine, it would be determined in the event of a dissenting opinion being submitted by the majority of the panel, e.g. by all lay judges (Świecki, 2017).

\section{Appeals against judgments with the participation of a jury}

While there are no significant differences in appeals against judgments issued by the panels composed of professional judges and those with the participation of representatives of the community, certain differences can be observed in the systems providing for the jury. They mainly result from a different trial position of jury members, which is a body fully based on 
representatives of the community. Therefore, the jury has a separate task than the professional judge conducting the trial and forming the judgment based on the jury's decision on the accused's guilt.

In the English criminal trial, the jury acts under the provisions of the Juries Act of 1974 and generally consists of 12 people drawn to adjudicate on a specific case before the Crown Courts. Its role is to hear the course of the court proceedings, during which the parties take evidence and give speeches - at the beginning and after the end of the evidentiary proceedings, and the whole judicial examination is summarized by the professional judge conducting the case (Kulesza, 2016).

Judgments given by the Crown Court with the participation of a jury may be appealed to the Court of Appeal in principle but to a very limited extent (Holdham, Beldam, 2012). In accordance with Section 2(1) of the Criminal Appeal Act of 1968, as amended by the Criminal Appeal Act of 1995, the Court of Appeal shall allow an appeal against conviction if they think that the conviction is unsafe, and shall dismiss such an appeal in any other case. In the judgment in the case $R$ vs. Criminal Cases Review Commission the meaning of the term "unsafe" was considered as not precise. It will be obvious in cases, for example, where it appears that someone other than the appellant committed the crime and the appellant did not, or where the appellant has been convicted of an act that was not in law a crime, or where a conviction is shown to be vitiated by serious unfairness of the trial or significant legal misdirection, or where the jury verdict, in the context of other verdicts, defies any rational explanation (Jones, Stewart, Bennathan, 2015). The restrictive interpretation of the above provisions expressed by the court in the judgment in the case $R$. vs. Chalkley has not been adopted. When deciding on the admissibility of an appeal the Court of Appeal is entitled to take into account also an unlawful incorrect decision or significant irregularities in the course of the trial which can include:

- wrongful admission or exclusion of evidence,

- failure to properly exercise judicial discretion,

- errors on the part of counsel (defender's incompetence per se does not make a conviction unsafe),

- defects in the indictment (e.g. improperly formulated points of the indictment, no signature on the indictment),

- mistakes by the trial judge (e.g. refusal to allow a counsel, accidental disclosure to the jury of information that they would not otherwise obtain, encouraging the jury to convict on the basis of evidence and facts that were not raised by the prosecutor), 
- errors in the trial judge's summing-up (e.g. incorrect orientation or lack of orientation of the jury by trial judge as to the significance of evidence, incorrect orientation as to facts, failure to leave the jury for consideration of the possibility of issuing an alternative verdict),

- interventions or discourtesy by the trial judge (e.g. insistently inviting the jury to disbelieve the evidence for the defence, making it impossible for the counsel for the defence to do his duty, preventing the defendant or a witness for the defence from telling his story in his own way),

- problems associated with jurors (e.g. incorrect composition of the jury, partiality of the jury, obtaining information by the jury about a case not coming from the court, conviction based on incorrect factual grounds),

- errors related to the announcement of the verdict by the jury (e.g. the jury chairman's refusal to provide information on the ratio of votes in the event of unanimity; contradictions in the judgment),

- fresh evidence regarding the facts that existed at the time of trial but were not known about at trial or regarding events that happened after conviction (Sanders, Young, 2007; Holdham, Beldam, 2012; Jones, Stewart, Bennathan, 2015; Hannibal, Mountford, 2015).

The procedure for appealing to the Court of Appeal is quite complicated. In the case of jury trials, pursuant to Section 1(1) of the 1968 Criminal Appeal Act, a person convicted on indictment may appeal to the Court of Appeal against his conviction. The condition for successful appeal is obtaining a leave to appeal granted by the Court of Appeal, usually composed of a single judge. A leave to appeal is not required if the trial judge from the Crown Court has issued a certificate that the case is suitable for appeal. It happens very rarely when there are particular and convincing grounds of appeal with serious chances of being considered by the Court of Appeal. To obtain a leave to appeal, a convicted person must submit to a judge a number of documents, including a notice of application for leave to appeal and grounds of appeal often together with an advice on appeal, a transcript of the trial judge's summing-up or a transcript of part of evidence. Only a positive assessment and granting of a leave to appeal by the judge allow to lodge an appeal (Sprack, 2015).

The Court of Appeal may dismiss the appeal or, if deemed justified, take one of four decisions:

- to quash the conviction, as a result of which the Crown Court is obliged to record a judgement and verdict of acquittal; if the appellant's appeal only on some charges of an indictment is allowed, the Court of Appeal may also review the sentence, however, in accordance with the reformatio in peius principle, the altered sentence must not be more severe than that imposed by the Crown Court, 
- to order pursuant to Section 7(1) of the Criminal Appeal Act of 1968 a retrial by the Crown Court if it appears that the interests of justice so require; if fresh evidence were heard by the court, a retrial will usually be ordered so that a jury can hear all evidence, unless the fresh evidence clearly shows that the appellant is Innocent and the Court of Appeal will have to quash the conviction,

- to order venire de novo proceedings, i.e. to find that there was never a valid conviction, because the proceedings were so irregular as to not constitute a proper trial which requires the proceedings to start again in the Crown Court; a writ of venire de novo may be issued due to serious procedural irregularities that prevent the proper start of the trial, e.g. improper formation of the jury,

- to substitute a conviction for an alternative offence pursuant to Section 3 Criminal Appeal Act of 1968; if the appellant has been convicted of an offence to which he did not plead guilty, and the jury could have found him guilty of another offence on the indictment, and on the finding of the jury it appears to the Court of Appeal that the jury must have been satisfied of facts which proved him guilty of the other offence, the court may substitute for the verdict of the jury a verdict of guilty of the other offence instead of allowing or dismissing the appeal (Hungerford-Welch, 2009; Jones, Stewart, Bennathan, 2015).

\section{Conclusions}

Regardless of the form and legal system, representatives of the community in the criminal trial are one of the most important guarantors of democratic and transparent criminal proceedings and a kind of control over the operation of trial authorities. The participation of representatives of the community in the administration of justice protects other citizens against the omnipotence of the state. The discourse taken during forming trial decisions is aimed at building citizens' confidence in the judiciary and the state itself and strengthening the legitimacy of state powers. Society, by way of the participation of its representatives in court proceedings, acquires knowledge and is able to formulate their own beliefs and assessments about the operation of the judiciary. The influence of representatives of the community on the administration of justice is a litmus test of democratic governance in a given country (Kulesza, 2016).

Two basic models of the participation of representative of the community in the administration of justice are based on the institution of lay 
judges and jury. Lay judges which have equal competences with professional judges in adjudicating panels shall issue a uniform judgment on both guilt, punishment and other matters. This model is closer to the continental tradition derived from statutory law. The Anglo-Saxon model of separation representatives of the community and professional judges is reflected in the division of tasks: the jury rules only on the guilt of the accused, and the professional judge, based on the jury's verdict, draws up the judgment in respect of other decisions.

The differences in the tasks of lay judges and jury determine significant procedural distinctions in criminal proceedings. The procedure used in the continental trial is more "uniform", there are no noticeable differences in regulations regarding proceedings before a professional panel (single or multi-person) and a panel with the participation of representatives of the community. Generally, the same scope of rights and obligations of the professional and the representative of the community, means that only technical issues related to the functioning of the collegial authorities require additional legal regulations. In practice, it is about rules for deliberation and voting on a judgement. The problem of possible unanimity, which can occur only in the collegial panels, is solved, as in the Polish legal system, with the aid of dissenting opinion. The disclosure of unanimity among members of the adjudicating panel does not constitute a separate appeal ground in the Polish Code of Criminal Procedure, but in practice it may be one of the arguments raised in the appeal. However, the grounds for appeal and the appeal procedure against judgments of all types of court panels are identical.

The specifics of the jury's trial position makes it necessary to regulate the issue of the possible scope of the appeal and the grounds of appeal separately as to the verdict on guilt and, if the accused is found guilty, as to the verdict on the remaining issues. In the case of a jury verdict, the scope of the appeal and possible trial decisions of the court of appeal is much narrower than in the case of a professional judge's judgment based on a jury decision. It is also characteristic to limit the possibilities of raising appeals against jury verdict to gross errors, mainly of a procedural nature. Moreover, the accused has more possibilities to appeal against conviction than the other parties against acquittal. Certainly, one of the factors that influences such a trend of law-making rulings in the common law system is faith and trust in the collective wisdom and the equity of verdicts passed by the so-called ordinary citizens who as the jury are emanation of the sovereign. 
Appealing the judgments issued in criminal trial with the participation...

\section{N O T E S}

1 Journal of Laws 1997, No. 78, item 483, as amended.

2 Consolidated text Journal of Laws 2017, item 1904.

3 The Supreme Court judgment of 12 September 1977, on case II KR 201/77, OSP 1980, no. 5 , item 90 .

4 The Supreme Court judgment of 19 May 1971, on case IV KR 83/71, OSP 1972, no. 6, item 111.

\section{R E F E R E N C E S}

Bartnik, A. S. (2009). Sędzia czy kibic? Rola tawnika w wymiarze sprawiedliwości III RP. Analiza socjologiczno-prawna. Warszawa.

Boratyńska, K., Czarnecki, P. (2018). In A. Sakowicz (Ed.), Kodeks postępowania karnego. Komentarz ( $8^{\text {th }}$ ed.). Warszawa.

Hannibal, M., Mountford, L. (2015). Criminal Litigation. Oxford.

Hofmański, P., Sadzik, E., Zgryzek, K. (2011). Kodeks postępowania karnego. Komentarz do artykutów 1-296. Tom I (4th ed.). Warszawa.

Hofmański, P., Sadzik, E., Zgryzek, K. (2011). Kodeks postępowania karnego. Komentarz do artykutów 297-46\%. Tom II (4th $\mathrm{ed}$.). Warszawa.

Hannibal, M., Mountford, L. (2015). Criminal Litigation. Oxford.

Holdham, S., Beldam, A. (2012). Court of Appeal Criminal Division: a Practitioner's Guide. London.

Hungerford-Welch, P. (2009). Criminal Procedure and Sentencing. Abingdon.

Janusz-Pohl, B. (2014). Zasada udziału czynnika społecznego. In P. Wiliński (Ed.), System prawa karnego procesowego. Tom III Cz. 2. Zasady procesu karnego. Warszawa,

Jones, D., Stewart, G., Bennathan, J. (2015). Criminal Appeals Handbook. Haywards Heath.

Kovalev, N. (2010). Criminal Justice Reform in Russia, Ukraine, and the Former Republics of the Soviet Union. Trial by Jury and Mixed Courts. LewistonQueenston-Lampeter.

Kulesza, C. (2016). Udział czynnika społecznego w orzekaniu w perspektywie historyczno-prawnoporównawczej. Białostockie Studia Prawnicze, 21.

Malsch, M. (2016). Democracy in the Courts. Lay Participation in European Criminal Justice Systems. London - New York.

Marszał, K., Zagrodnik, J. (2017). Proces karny. Warszawa.

Sanders, A., Young, R. (2007). Criminal Justice. Oxford.

Sikich, K.W. (2013). Explaining the Presence of the Criminal Jury in Democratic Political Systems. Washington D.C. 
Sprack, J. (2015). A Practical Approach to Criminal Procedure. Oxford.

Świecki, D. (2015). In J. Skorupka (Ed.), Kodeks postępowania karnego. Komentarz. Warszawa.

Wieczorek, K. (2012). Udział czynnika społecznego w orzekaniu w polskim i amerykańskim procesie karnym. Szczecin.

Włodyka, S. (1975). Ustrój organów ochrony prawnej. Warszawa.

Zawadzki, S., Kubicki, L. (1970). Udziat ławników w postępowaniu karnym. Opinie a rzeczywistość. Studium prawnoempiryczne. Warszawa. 